\title{
A Short Review on "Water Management in Onion”
}

\author{
Khalid Mahmud Khokhar* \\ Vegetable Crops Research Programme, Horticulture Research Institute, National Agricultural Research Centre, Pakistan
}

Submission: May 15, 2018; Published: June 06, 2018

*Corresponding author: Khalid Mahmud Khokhar, Vegetable Crops Research Programme, Horticulture Research Institute, National Agricultural Research Centre, Park Road, Islamabad, 44000, Pakistan, Email: Tokmahmud@yahoo.com

\begin{abstract}
Being a shallow-rooted crop, onion extracts most of the water from the top $30 \mathrm{~cm}$ of soil and is more sensitive to water stress during bulb formation and enlargement than during the vegetative stage. Lack of irrigation results in a shorter duration of bulb growth, a lower percentage radiation interception and a lower efficiency of conversion of radiation to dry matter and all these contribute to lowered bulb yield.
\end{abstract}

Keywords: Onion; Water management; Water stress; Bulb growth

\section{Introduction}

The cultivated onion (Allium cepa L.) is an important crop with world production of about 84.76 million metric tonnes for the year 2013-2014 [1]. Water is the main limiting factor for low bulb yield in onion. The crop requires $350-500 \mathrm{~mm}$ of water over the growing season [2]; hence, adequate moisture through irrigation is important in the production of onions. Being a shallow-rooted crop, onion is more sensitive to water stress and therefore the production of bulbs and dry mat?ter are highly dependent on the availability of soil water [3-11]. Frequent irrigation is required to maintain high soil moisture to produce high yields of onion [12-14]. Moreover, since onion shows the reduction of both evapotranspiration rate and yield under water deficit, irrigation is necessary to obtain the optimum size and weight of bulbs, especially during the stage of bulb development [14,15].

Notably, the highest yield of onion bulbs occurs when the soil is constantly kept moist but the irrigation is performed until two weeks before harvest, which also prevents rot and sprouting during storage [16-18]. However, excessive irrigation during the vegetative period may lead to a delayed and attenu $\neg$ ated development of bulbs [19]. As for bulb quality, total soluble solids significantly increase with the increase of soil moisture, may be due to both the fulfillment of crop water demand and the use of nutrients under optimum availability of soil moisture $[16,20]$; protein content shows the opposite trend [20].

Water stress during the critical growth period causes reduction in size and weight of onion bulbs $[14,15,21,22]$. Onions under water deficiency decrease evapotranspiration and consequently yield [23]. Drought stress during the last 3 weeks of the season reduces onion yields [24]. Soilwater stress caused by withholding irrigation at both the 3 and 7-leaf stages reduced bulb yield by $26 \%$ compared with the control [25]. When water stress was imposed 30 days after transplanting for a period of 15 days, leaf area and bulb growth was considerably decreased with a reduction of $17-26 \%$ in onion yield [26]. When water stress imposed for a period of 3 weeks, caused a greater reduction in photosynthetic rate, total plant dry matter accumulation, bulb dry matter and bulb size [27]. Appropriate water supply during the development and ripening stages increased bulb yield [21,28-30]. Higher water supply increased double and bolter while decreased exportable bulbs [31]. Water deficit during crop cycle leads to a significant reduction of bulb size, which suggests the need to finely adjust water management in this crop [22].

\section{Conclusion}

Irrigation has a significant effect on the growth and quality of onion, which is significantly affected by the volume of water supplied. Water stress results in reduced yield of marketable bulbs due to earlier ripening of bulbs. Appropriate water supply during the development and ripening stages increases bulb yield Monitoring soil moisture is therefore important to determine when irrigation may be needed.

\section{References}

1. FAOSTAT (2015) World Food and Agriculture Organization, Rome, Italy.

2. FAO (2013) Crop water information: onion.

3. Imtiyaz M, Singh SJ (1990) The effect of soil moisture stress on onion: evapotranspiration-yield relationship. In: Salokhe VM, and Ilangantilike SG (Eds.), Proceedings of the International Agricultural Engineering Conference and Exhibition, Bangkok, Thailand 889-898.

4. De Santa Olalla FM, Valero JAJ, Cortes CF (1994) Growth and production of onion crop (Allium cepa L.) under different irrigation scheduling. European Journal of Agronomy 3: 85-92.

5. Koriem SO, El-Koliey MM, Wahba MF (1994) Onion bulb production from "Shandwee 1" sets as affected by soil moisture stress. Assiut Journal of Agricultural Sciences 25: 185-193. 
6. Martin D, Brocklin J, Van Wilmes G (1994) Operating rules for deficit irrigation management. American Society of Agricultural Engineers Publications 22: 1207-1215.

7. Prashar CRK, Sharma GC, Gandah M (1994) Evapotranspiration of onion in Sahelian Niger. Experimental Agriculture 30(4): 473-476.

8. Sharma OL, Katole NS, Gautam KM (1994) Effect of irrigation schedules and nitrogen levels on bulb yield and water use by onion (Allium cepa L.). Agricultural Science Digest Karnal 14(1): 15-18.

9. Thabet EMA, Abdallah AAG, Mohammed ARAG (1994) Productivity of onion grown in reclaimed sandy soil using Tafla as affected by water regimes and nitrogen levels. Annals of Agricultural Science 39(1): 337 344.

10. Saha UK, Khan MSI, Haider J, Saha RR (1997) Yield and water use of onion under different irrigation schedules in Bangladesh. Japanese Journal of Tropical Agriculture 41(4): 268-274.

11. Shock CC, Feibert EBG, Saunders LD (2000) Irrigation criteria for dripirrigated onion. HortScience 35(1): 63-66.

12. Rana DS, Sharma RP (1994) Effect of irrigation regime and nitrogen fertilization on bulb yield and water use of onion (Allium cepa L). Indian Journal of Agricultural Sciences 64: 223-226.

13. Al-Jammal MS, Sammis TW, Ball S, Smeal D (2000) Computing the water production function for onion. Agricultural Water Management 46: 29-41

14. Kadayifci A, Tuylu Gİ, Ucar Y, Cakmak B (2005) Crop water use of onion (Allium cepa L.) in Turkey. Agricultural Water Management 72(1): 5968.

15. Chung B (1989) Irrigation and bulb onion quality. Acta Horticulturae 247: 233-238

16. Chopade SO, Bansode PN, Hiwase SS (1998) Studies on fertilizer and water management to onion. PKV Research Journal 22: 44-47.

17. Shock CC, Erik BGF, Saunders LM (2004) Plant population and nitrogen fertilization for subsurface drip-irrigated onion. HortScience 39(7): 1722-1727.

18. De Santa Olalla FM, Dominguez-Padilla A, Lopez R (2004) Production and quality of the onion crop (Allium cepa L.) cultivated under controlled deficit irrigation conditions in a semi-arid climate. Agricultural Water Management 68(1): 77-89.

19. Doorenbos J, Kassam AH (1979) Yield response to water. FAO Irrigation and Drainage Paper 33, Rome, Italy, p. 193.

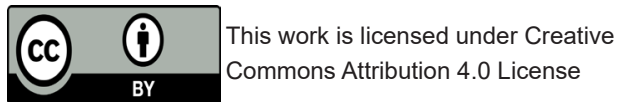

20. Kumar S, Imtiyaz M, Kumar A (2007) Effect of differential soil moisture and nutrient regimes on postharvest attributes of onion (Allium cepa L.). Scientia Horticulturae 112(2): 121-129.

21. Bekele S, Tilahun K (2007) Regulated deficit irrigation scheduling of onion in a semiarid region of Ethiopia. Agricultural Water Management 89(1-2): $148-152$.

22. Rattin JE, Assuero SG, Sasso GO, Tognetti JA (2011) Accelerated storage losses in onion subjected to water deficit during bulb filling. Scientia Horticulturae 130(1): 25-31.

23. Sammis TW, Al-Jammal MS, Ball S, Smeal D (2000) Crop water use of onion. In: Proceedings of the 6th international micro irrigation congress, micro. Cape Town. International Commission on Irrigation and Drainage (ICID), Rome, Italy pp. 1-9.

24. Sorensen JN, Grevsen K (2001) Sprouting in bulb onions (Allium cepa L.) as influenced by nitrogen and water stress. Journal of Horticultural Science and Biotechnology 76(4): 501-506.

25. Gary Q, Mittelstadt R, Leib G, Redulla B, Cristoti A (2004) Effects of water stress at specific growth stages on onion yield and quality. Agricultural Water Management 68(2): 107-115.

26. Bhatt RM, Srinivasa Rao NK, Veere Gowda R (2006) Response of bulb onion (Allium cepa L.) to water stress: photosynthesis, stomatal conductance and osmotic adjustment. Indian Journal of Horticulture 63(3): 20-25.

27. Srinivasa Rao NK, Laxman RH, Bhatt RM (2010) Extent of impact of flooding and water stress on growth and yield of onion and tomato. In: Aggarwal PK (ed) Annual progress report of ICAR network project impact, adaptation and vulnerability of Indian Agriculture to climate change. pp 111-112.

28. Mermoud A, Tamini TD, Yacouba H (2005) Impacts of different irrigation schedules on the water balance components of an onion crop in a semi-arid zone. Agricultural Water Management 77(1-3): 282-295.

29. Enciso J, Wiedenfeld B, Jifon J, Nelson S (2009) Onion yield and quality response to two irrigation scheduling strategies. Scientia Horticulturae 120(1): 301-305.

30. Patel N, Rajput TBS (2013) Effect of deficit irrigation on crop growth, yield and quality of onion in subsurface drip irrigation. International Journal of Plant Production 7(3): 417-436.

31. Metwally AK (2011) Effect of water supply on vegetative growth and yield characteristics in onion (Allium cepa L.). Australian Journal of Basic and Applied Sciences 5(12): 3016-3023.

\section{Your next submission with Juniper Publishers will reach you the below assets}

- Quality Editorial service

- Swift Peer Review

- Reprints availability

- E-prints Service

- Manuscript Podcast for convenient understanding

- Global attainment for your research

- Manuscript accessibility in different formats

( Pdf, E-pub, Full Text, Audio)

- Unceasing customer service

Track the below URL for one-step submission https://juniperpublishers.com/online-submission.php 